\title{
Project Review: Arun III Hydroelectric Project
}

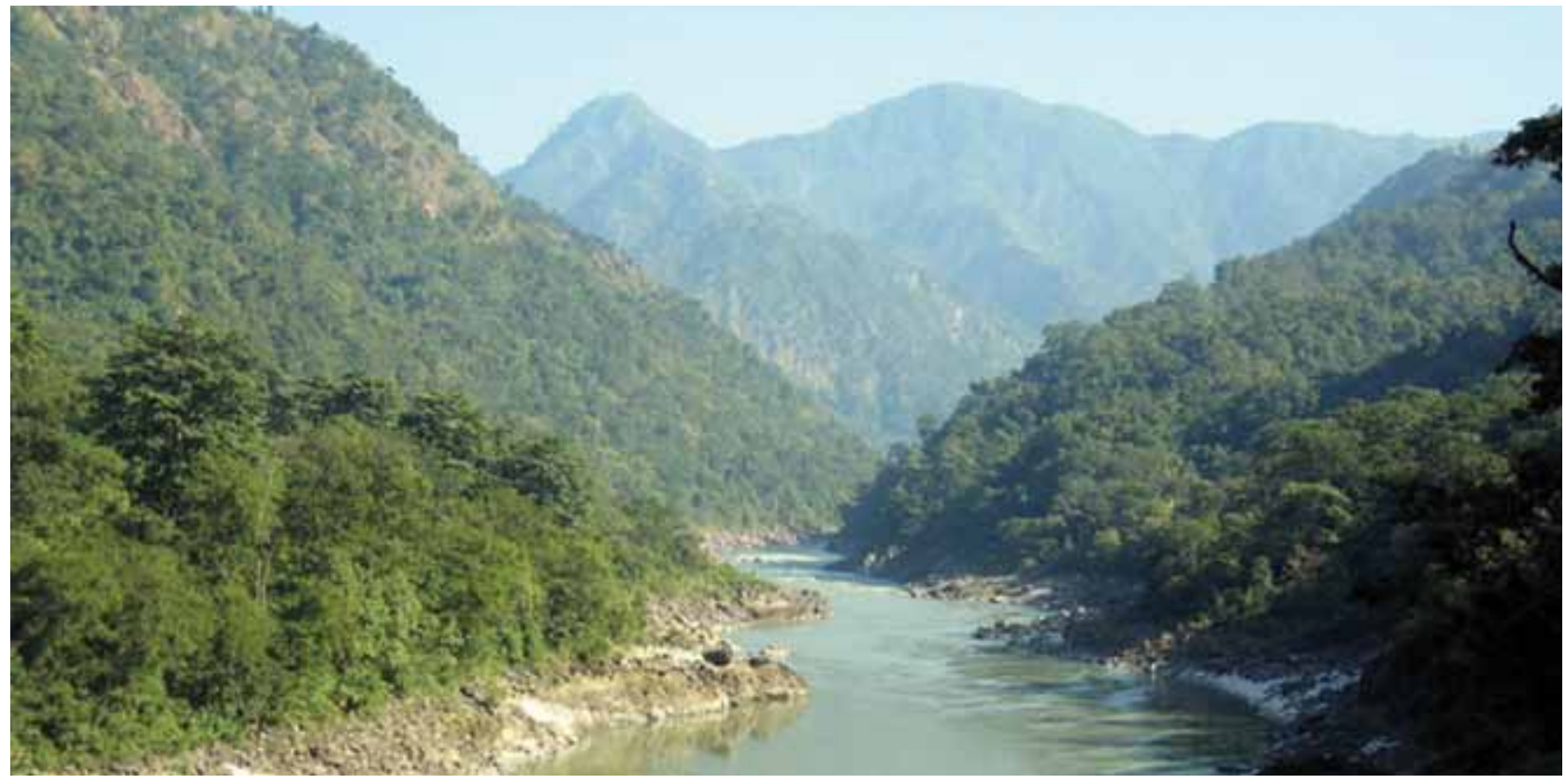

\section{Background}

The Investment Board Nepal (IBN) and the Indian developer Satluj Jal Vidyut Nigam Limited (SJVN Limited) have signed the Project Development Agreement (PDA) on a 900 MW Arun III Hydroelectric Project on November 25, 2014. The PDA was signed on the sidelines of the SAARC Summit in the presence of Prime Minister of Nepal Sushil Koirala and Indian PM Narendra Modi.

The IBN and SJVN Limited started PDA talks in 2013 after Nepal and India signed a Memorandum of Understanding with the Govt. of Nepal for the execution of 900 MW Arun - III HEP on March 2, 2008.

\section{Introduction}

The Arun River is one of the major tributary of the Koshi River in the Sapta Koshi basin. The catchment area of the project is $26747 \mathrm{~km}^{2}$ upstream from the proposed Dam site. The Project envisages utilization of a design discharge of $342.23 \mathrm{~m}^{3} / \mathrm{s}$ through an effective head of $308 \mathrm{~m}$ in order to generate a maximum of $900 \mathrm{MW}$ of power. The scheme shall have a $68 \mathrm{~m}$ high Dam; a $11.74 \mathrm{~km}$ headrace tunnel and an underground cavern powerhouse with four Vertical Francis Turbine-driven generating units each of $225 \mathrm{MW}$ with an annual average energy production of $3684.651 \mathrm{GWh}$. The estimated cost of the project is NRs. 104 billion.

\section{Location and Accessibility}

Arun-III Hydroelectric Project is a Run-of-River scheme, located on the River Arun in Sankhuwasabha District in eastern development region of Nepal. The closest point of road access is Num Bazaar, which is close to the proposed dam site of the Project. Num Bazaar can be reached from Kathmandu by taking a flight to Tumlingtar, then driving approximately $15 \mathrm{~km}$ on an all season road to Khandbari, followed by approximately 40 $\mathrm{km}$ on a fair weather road. The fair weather stretch is planned to be upgraded to an all season road.

\section{Project Proponent}

The project proponent company is SJVN Arun - 3 Power Development Company Pvt. Ltd.

(SAPDC). SAPDC is sole undertaking of Satluj Jal Vidyut Nigam Limited. SJVN Limited is a joint venture company between the Govt. of India (with 74.5\%) and Govt. of Himachal Pradesh (with 25.5\%) which is incorporated in the year 1988 .

The project will affect 203 houses located in six VDCs of Sankhuwasabha District. The project will carry 
out rural electrification in affected areas under which affected households will receive 30 units energy free each month. As per the PDA, the Indian company will allot Rs 1.6 billion worth of shares to the locals. Fifty

\section{Salient Features}

\begin{tabular}{|l|r|}
\hline Capacity & $900 \mathrm{MW}$ \\
\hline Basin & Arun \\
\hline Project Type & Run-of-River \\
\hline Type of Dam & Concrete Gravity Dam \\
\hline Height of Dam & $68 \mathrm{~m}$ \\
\hline FRL & $849 \mathrm{~m}$ \\
\hline Nos. of Sluice Gates & 6 \\
\hline Crest Level & $808 \mathrm{~m}$ \\
\hline Length/ Dia of DT & $466 \mathrm{~m} / 11 \mathrm{~m}$ \\
\hline No. of Intakes & 4 \\
\hline Desilting Chambers & Underground, 4 nos. 420 m \\
(L)x16m(W)x 24m(H)
\end{tabular}

\begin{tabular}{|l|r|}
\hline Type of Surge Shaft & one, orifice Type \\
\hline Height of Surge Shaft & $149 \mathrm{~m}$ \\
\hline Dia & $24 \mathrm{~m}$ \\
\hline Type of Pressure Shaft & vertical steel lined \\
\hline $\begin{array}{l}\text { No. of Pressure Shaft(s)/ } \\
\text { Penstocks }\end{array}$ \\
\hline Type of Powerhouse \\
\hline $\begin{array}{l}\text { No./ Capacity of generat- } \\
\text { ing units }\end{array}$ \\
\hline Type of Turbine & Underground Cavern \\
\hline Gross Head & Francis \\
\hline Design Head & $308 \mathrm{~m}$ \\
\hline $\begin{array}{l}\text { Length/ dia of TRT/Tail } \\
\text { Race Tunnel }\end{array}$ & $287 . \mathrm{m}$ \\
\hline $\begin{array}{l}\text { Energy in 90 \% } \\
\text { Dependable Year }\end{array}$ & $212 \mathrm{~m} / 10 \mathrm{~m}$ \\
\hline
\end{tabular}

\section{References:}

1. Arun III Hydroelectric Project (2015). Retrieved 25 July, 2015, from http://sjvn.nic.in/

2. http://www.investmentboard.gov.np/ Retrieved 26 July, 2015

Presented by: Keshab Pyakurel Victoria University, Australia 